\title{
How Well do Canadian Distance Education Students Understand Plagiarism?
}

\section{Abstract}

This project ascertains how well students taking online, distance education courses at a Canadian university recognize plagiarised material and how well they paraphrase. It also assesses the types of errors made. Slightly more than half of 420 psychology students correctly selected plagiarised phrases from four multiple choice questions. Only a minority was able to rewrite a phrase properly in their own words. A more diverse sample of university students also had difficulty recognizing plagiarised passages from multiple choice options. The poor ability of students to identify plagiarised passages may suggest poor understanding of the concept. Students may benefit from training to improve their understanding of plagiarism.

Keywords : Distance education; higher education; online learning 
Alarming numbers published in academic journals and the media produce the perception that plagiarism is a widespread and urgent problem (e.g., Briggs, 2009; Chai, 2010). However, the actual prevalence of plagiarism is unknown, as most data come from self-reports (Dee \& Jacob, 2012; Walker, 2010). If students do not fully understand what constitutes plagiarism, the accuracy of self-reports is questionable, even if students are being truthful. Although several recent studies have examined plagiarism (Dee \& J acob, 2012; Holt, 2012; Kirsch \& Bradley, 2012), more needs to be known about actual student behaviour as well as understanding. This project assesses Canadian distance education students' knowledge of plagiarism by (1) asking them to select plagiarised (or non-plagiarised) passages from a number of choices; (2) having them produce a paraphrase using their own words; (3) implementing a simple exercise aiming to improve understanding; (4) analyzing the types of errors made.

The literature on plagiarism as cheating will be presented. This is followed by a review of the research on plagiarism in online courses and then a discussion of evidence suggesting that student knowledge about plagiarism is limited. Empirical data collected from a high-enrollment online psychology course is then presented, followed by data from a wider sample of the university. The data support the notion that many students do not fully comprehend plagiarism and therefore might benefit from more education about it.

\section{The Extent of the Problem}

Although there are several types of plagiarism (Briggs 2009; Turnitin, 2012), this paper focuses on instances in which words are copied verbatim, often known as "copy and paste" plagiarism (J ocoy \& DiBiase, 2006; J ones, 2011). (Note that this is referring to the copying of a few passages, not reproducing an entire article.)

\section{Purposeful plagiarism.}

In confidence, many students admit that they have copied word-for-word from textbooks or websites. This has been found in post-secondary institutions in Australia (Zimitat, 2008), the United States (both undergraduate students; McCabe \& Trevino, 1993; Scanlon \& Neumann, 2002; and graduate students; McCabe, 2009), and in the United Kingdom (Szabo \& Underwood, 2004).

Why is the rate of purposeful plagiarism so high? Students tend to downplay the importance of this (Breen \& Maassen, 2005; Thomson Maddox, 2008). As Park (2003, p. 476) and MoCabe (2005, p. 26) discovered, many students think copying a few words here and there is not a "big deal". Partly because students see university papers as reviews of other people's work rather than production of original thought, many do not view copy and paste plagiarism as severe cheating (Ashworth, Bannister, \& Thorne, 1997; Baker, Berry, \& Thornton, 2008).

Scanlon (2003) suggests this blasé attitude is encouraged when there are no harsh penalties for being caught. Evidence exists to support the idea that many students do get 
away without strong penalties. Some faculty members simply give verbal warnings (Szabo \& Underwood, 2004). They are often hesitant to follow up on suspected plagiarism (Ercegovac \& Richardson, 2004; McCabe, 2009), some because they feel the administration does not support them, others because they believe it is not their role to police students (McCabe, 2005).

Another major reason for cheating (including plagiarising) is the pressure many students feel to get good grades (Ellery, 2008; Christensen-Hughes \& McCabe, 2006). Often students care more about their grades than about their learning (Park, 2003).

Some authors suggest that plagiarism is what students are used to, because they used various plagiarist activities successfully during their secondary education (Davis \& Ludvigson, 1995; Hansen, 2003). It may be that this begins even earlier (Sciammarella, 2009).

Students working in a second language have higher rates of plagiarism than native speakers (Ellery, 2008; Marshall \& Garry, 2005). There are a number of reasons for this, including general difficulty with the language and different cultural attitudes toward sharing and expression of ideas (Christensen-Hughes \& McCabe, 2006; Park, 2003). One study did find that native English speakers engaged in more plagiarism than non-native speakers. It is not clear why these results differ from those of other studies (Soto, Anand, \&McGee, 2004).

\section{To what extent does plagiarism occur with online courses?}

Given the relatively recent use of online learning on a large scale, the extent of plagiarism in online courses has not been explored as much as plagiarism in traditional institutions. Many believe that widespread use of the Internet has increased plagiarism. Some researchers note that the Internet makes it easier to find, copy and paste material, hire writers or editors, or purchase complete essays, so students are more tempted than before (Kennedy, Nowak, Raghuraman, Thomas, \& Davis, 2000; Stuber-McEwen, Wiseley, \& Hoggatt , 2009). Others focus on the feelings of detachment (Kennedy et al., 2000; Stuber-McEwan et al., 2009) or perceived lack of contact between students and instructor (Kasprzak \& Nixon, 2004) when studying at a distance that may also increase temptation.

Other research suggests there is no more cheating in online classes than in face-to-face classrooms (Scanlon \& Neumann, 2002; Varvel, 2005). In fact, some researchers found the amount of cheating (including plagiarising) among undergraduate students studying online was lower than that for students attending campus courses at the same university (Stuber-McEwen et al., 2009; Walker, 2010).

The degree to which plagiarism is committed in online courses remains uncertain. Similarly, there is continuing debate about whether students plead ignorance to avoid paying the consequences for being caught in the act of plagiarism, or if some really do 
not know what constitutes plagiarism. A review of the evidence suggesting plagiarism may be unintentional follows.

\section{Accidental Plagiarism}

Voss and Rosati (2002) recount an anecdote in which a professor announced in class that the three people who plaigiarised a particular assignment should come to her office. Fourteen students showed up! This suggests that there is a considerable portion of students (and/or faculty members!) who do not know exactly what plagiarism is. Another example comes from Hansen (2003, p. 780), who reported that McCabe (no date), who conducted several large self-report studies on academic misconduct, found evidence of ignorant plagiarism: "When I debrief a small percentage of them [after a survey], some of them say, Yeah, I did that but I don't consider it cheating so I didn't check it off."' This suggests many students likely engage in misconduct inadvertently rather than as an attempt to cheat.

Along with anecdotes, studies providing different scenarios of possible ways to use text reveal many postsecondary students are not fully aware of what constitutes plagiarism. A large percentage did not know that using some sentences from an original source with a minor change to a couple of words is considered plagiarism (Ellery, 2008; Marshall \& Garry, 2005). Many students believe it is perfectly okay to take a few word-for-word phrases from the original text and string them together with the students' words (Marshall \& Garry, 2005; Zimitat, 2008). A common belief is that sources only need to be cited when direct quotes are used (Ellery, 2008; Zimitat, 2008) or that acknowledging the source means quotation marks are not needed (Ellery, 2008; Soto et al., 2004). Another common belief is that if authors provide a reference list they do not need to include citations in the body of the paper (Ellery, 2008). One of the few Canadian studies found many students use some sources that are not acknowledged in the reference list without thinking twice (J urdi, Hage, \& Chow, 2012). Surprisingly, students view copying from the Internet as not very serious, or at least not as serious as copying from books (Baker et al., 2008; Hansen, 2003; Marshall \& Garry, 2005). Many also believe they do not need to cite Internet sources (Ellery, 2008). Clearly there is much misunderstanding.

Further evidence of ignorance about plagiarism comes from studies that let students know in advance that plagiarism would be targeted by using Turnitin plagiarism detection (word matching) software. Often students engaged in plagiarism despite this warning (Soto et al., 2004; Walker, 2010). Informal interviews with students who had plagiarised despite being told that plagiarism would specifically be looked for revealed, "most seemed perplexed about why they were considered to have plagiarised, and all were seeking better guidance than had been provided in this regard" (Ellery, 2008, p. 511).

Asking students to identify plagiarised passages indicates many students perform poorly. Roig (1997) reported almost half of his sample of 316 undergraduates claimed six of 
eight plagiarised versions of a single paragraph were not plagiarised. Similarly, J ones (2011) found that only half of the 48 students in her online business course correctly identified all nine scenarios of plagiarism presented. None of the 128 university students tested by Hochstein, Brewer, Steinke, and Taylor (2008) correctly categorized all 16 items as plagiarised or not. Most passages were recognized correctly by only $63 \%$ of individuals. Of over 2800 students who took Jackson's (2006) online tutorial, more than a quarter (29\%) failed to recognize that a sample passage was plagiarised in the pre-test. Hale (1987) found $73 \%$ of his 109 students identified passages correctly. However, $11 \%$ of students misjudged a plagiarised passage as being an adequate paraphrase. Hale argued his results demonstrated that students do actually recognize plagiarism well, but they also indicate that a substantial number of students do not. The fact that many students have trouble recognizing plagiarism suggests they may not fully understand what it is.

Taken together, research suggests that students do not fully understand the concept of plagiarism, and therefore may be committing it accidentally. However, more studies are needed on student behaviour in addition to their recognition ability. Discovering the areas in which students are having difficulty is an important step toward designing prevention programs.

\section{Preventing Plagiarism}

There have been several attempts to prevent plagiarism, some more effective than others. A few found that students who received instruction later plagiarised less than those without instruction, but still continued to commit plagiarised acts (Jocoy \& Dibiase, 2006; Soto et al., 2004). Exposing students to "real-world" examples of plagiarism improved their recognition of plagiarism and their paraphrasing ability better than did a feedback session (Landau et al., 2002). Moniz, Fine, and Bliss (2008) found all groups made "significant gains" (p. 277) (details lacking) on a plagiarism knowledge and recognition task, regardless of whether they received one session of interactive instruction, a didactic Powerpoint session, or a session in which students role-played a scenario about plagiarism. Barry (2006) found that students' definitions of plagiarism significantly improved after practice in paraphrasing, and also were significantly better than students without such practice. However, she did not assess whether there were differences in actual plagiaristic behaviour.

Shirley (2004) claimed success in using six face-to-face paraphrasing exercises involving the whole class over four sessions. Other instructors may find this too timeconsuming. A promising approach comes from studies helping students achieve "authorial identity" (Elandera, Pittam, Lusher, Fox, \& Payne, 2010, p. 157; Vardi, 2012). This involves sessions helping students develop their own voices, however can be quite time-intensive. Another interesting approach comes from Kirsch and Bradley (2012), who created a workshop with interactive multimedia activities and information regarding plagiarism, paraphrasing, citations, and more. Theirs is a work in progress, 
but they were able to conclude that students have most difficulty in paraphrasing and common knowledge, even after taking the workshop.

Walker (2008) was partially successful in uncovering the types of errors students made by creating a coding system to detect different types of plagiarised text:

1) word strings, that is lifting exact phrases consisting of five-to-nine words from the original 2) substitutions, modifying the original text by using one to two synonyms; 3) additions, including one-to-two new words to the original 4) deletions, eliminating one-to-four words from the original; and, 5) reversals, rearranging sentence order or interchanging phrases. (p. 390)

She found that training a randomly selected group of 19 students to paraphrase properly significantly reduced all five types of plagiarism in comparison to a control group of 17 students, although there was no difference in use of word strings for a second, lengthier passage. The fact that students benefitted from this training suggests that they may be uninformed about plagiarism, but can learn with intervention.

It seems that more research is needed to determine the circumstances in which training is useful and perhaps the types of training that suit particular audiences. Time-limited training is also an issue.

Unfortunately, many of the ideas for plagiarism prevention are not relevant for an online, distance education institution. At the present institution, many students are not enrolled in a program, but take only one or two courses and transfer these credits to their 'home' institution. Another difference from traditional universities is that students are admitted on a continuous basis, so only a small number start the course at the same time. This makes it more difficult to have students attend real-time workshops or information sessions on plagiarism, as Sciammarella (2009) and others suggest. Unlike what is recommended for traditional universities (e.g., McCabe, 2009), an honour code would also be difficult to implement. Waiting for students to go through the process of learning to write over their academic career, by first engaging in a process of "patchwriting" (Howard, 1995; Zimitat, 2008), is not an option when students are taking only one course in order to facilitate their degree at another institution. Many researchers suggest that students need time and practice to develop writing skills for academia, so they continue to develop these skills over the years of their degree (Ellery, 2008; Vardi, 2012). Yet students taking one online course may not have the necessary time required.

Because insufficient research exists on the topic of plagiarism, the present study assesses whether students recognize plagiarised work in which wording from the original had been changed in various ways. One group (the Psychology students) receives feedback on their recognition attempts and later is asked to paraphrase a 
passage. The prediction is that with feedback and practice, this group should improve over time. It is also expected that this improvement will transfer to their attempt to paraphrase without plagiarising. A second group of more diverse students (the University group) is tested to see if the results generalize. The types of errors made, based on Walker's (2008) definitions, will be assessed for descriptive purposes, but no hypotheses are offered.

\section{Method}

\section{Participants}

Eighty-five percent of 497 students $(\mathrm{N}=420)$ who registered in the Psychology of Adolescence course from August 8, 2007 to November 9, 2010 completed all five course quizzes and are included in this report. This study analyzed the data obtained from the questions about plagiarism. The university's Research Ethics Board provided permission to use student data for the purposes of the present study. The majority of students (87\%) was female with a mean age of 29. Most (44\%) lived in Alberta, and $2.2 \%$ were international students. The remainder lived in other Canadian provinces or territories.

As part of a larger study on academic integrity, a second group of participants from the same university (the University group) received a different set of scenarios. This group consisted of undergraduate ( $N=125 ; 71 \%$ female) and graduate students ( $N=103 ; 73 \%$ female) from Arts, Business, Communications, J ournalism, Nursing, Allied Health Studies, Math, Science, Social Sciences, and Interdisciplinary Studies. The undergraduate students were spread roughly equivalently across the four years of university and all students were taking at least one course online at a distance.

\section{Procedure}

Psychology of Adolescence is a fully online distance education course. Built into the course is a series of five quizzes, each consisting of 15 multiple choice questions and five short answer questions. Students read a portion of their textbook and study guide, and then took an online quiz before proceeding to the next readings. Most quiz questions were related to course content, but for the first four quizzes, one multiple choice question from each involved recognizing plagiarism. For this question, a passage from the textbook was presented. Students were asked to select one of four options that did or did not represent plagiarism of that passage. Because students receive feedback from markers, it was expected that the markers' feedback would increase students' awareness of plagiarism so their ability to recognize it would improve throughout the course. It was also predicted that because of this learning, they would paraphrase well when asked to do so in the fifth quiz. Students came from a variety of educational 
backgrounds, so the extent to which they had been taught or read about paraphrasing and plagiarism is unknown.

The plagiarism question in the fifth quiz was not a multiple choice question. Instead, a passage from the textbook was presented and students were asked to "Read the following passage from page 429 of your textbook."

'Although nearly all Trukese males in their teens and twenties engage in these activities, their externalizing escapades are limited to the weekends, and they rarely drink or fight during the week.' Write the above passage in your own words in a way that does NOT constitute plagiarism.

For the second group of students (the University group), students from throughout the university (rather than from a single course) were randomly selected to be invited to participate in a larger study on academic integrity. This article reports on the questions related to recognizing plagiarism. Aside from the fact that all scenarios included a proper citation, three scenarios were similar to those given to the Psychology students in that they involved multiple choice items asking students to identify whether a particular paraphrase was plagiarized or not. A fourth multiple choice question asked participants to identify what was wrong with a paraphrased passage. These students answered all questions at one point in time and did not receive any feedback on their answers.

\section{Coding System for Paraphrased Passages}

The fifth quiz for the Psychology students, which asked them to paraphrase a short passage in their own words, was coded according to a modified version of Walker's (2008) coding system. Instances of plagiarised text were tagged if there were three or more exact words from the original text (word strings), one to two synonyms used in place of the original words (substitutions), insertions of one to four new words into the original passage (additions), one to four words removed from the original text (deletions), and a different ordering of words from the original passage (reversals). The coding was conducted by a research assistant who was blind to the purpose of the study, but who had experience dealing with plagiarised material.

\section{Results}

Slightly more than half of the 420 Psychology students ( $n=215 ; 50.8 \%$ ) correctly classified all four items as plagiarised or not. The remaining students correctly answered between none and three questions. See Table 1 for numbers and percentages of students who correctly answered the four quiz questions on plagiarism. 
Table 1

Numbers and Percentages of Psychology Students who Correctly Answered the Four Quiz Questions on Recognizing Plagiarism

$\begin{array}{lcc}\text { Number of questions correct } & \text { N } & \text { Percent of students } \\ \text { All four questions correct } & 215 & 50.8 \% \\ \text { Only three questions correct } & 119 & 28.0 \% \\ \text { Only two questions correct } & 67 & 15.8 \% \\ \text { Only one question correct } & 17 & 4.00 \% \\ \text { No questions correct } & 5 & 1.20 \%\end{array}$

Most students got the first question correct (93.8\%), followed by the fourth question (82.2\%), the second question (75.5\%), and finally the third question (71.5\%). Table 2 shows the number and percentage of responses for each option.

Table 2

Number and Percentage of Psychology Students Choosing Each Option for the Four Quiz Questions

\begin{tabular}{|c|c|c|}
\hline & QUIZ1 & \\
\hline Option & $\begin{array}{l}\text { Read the following passage from page } 13 \text { of your textbook: "For } \\
\text { now, however, it should be emphasized that even though there is } \\
\text { evidence to support a modified storm and stress view, this does } \\
\text { not mean that storm and stress is typical of all adolescents in all } \\
\text { places and times." Which of the following is NOT plagiarised from } \\
\text { the above passage? }\end{array}$ & $\begin{array}{l}\text { N chosen } \\
\text { (\%) }\end{array}$ \\
\hline $\mathrm{a}$ & $\begin{array}{l}\text { It should be emphasized that even though there is evidence to } \\
\text { support a modified storm and stress view, this does not mean that } \\
\text { storm and stress is typical of all adolescents in all places and } \\
\text { times. }\end{array}$ & $\begin{array}{l}2 \\
(.92 \%)\end{array}$ \\
\hline $\mathbf{b}$ & $\begin{array}{l}\text { Many, but not all, adolescents experience some aspects } \\
\text { of storm and stress at some point in their development. }\end{array}$ & $\begin{array}{l}205 \\
(94.5 \%)\end{array}$ \\
\hline C & $\begin{array}{l}\text { For now, however, it should be emphasized that even though } \\
\text { there is evidence to support a modified storm and stress view, this } \\
\text { does not mean that storm and stress is typical of all adolescents in } \\
\text { all places and times. }\end{array}$ & $\begin{array}{l}4 \\
(1.8 \%)\end{array}$ \\
\hline $\mathrm{d}$ & $\begin{array}{l}\text { Although there is evidence to support a modified storm and stress } \\
\text { view, this does not mean that storm and stress is typical of all } \\
\text { adolescents in all places and times }\end{array}$ & $\begin{array}{l}6 \\
(2.8 \%)\end{array}$ \\
\hline
\end{tabular}




\begin{tabular}{|l|l|l|}
\hline & QUIZ2 & \\
\hline Option & $\begin{array}{l}\text { Read the following passage from page 177 of your textbook. “Had } \\
\text { Luther grown up in a different time and place, he would have } \\
\text { developed a much different identity.” Which of the following does } \\
\text { NOT constitute plagiarism of the passage? }\end{array}$ & $\begin{array}{l}\text { N chosen } \\
\text { (\%) }\end{array}$ \\
\hline a & $\begin{array}{l}\text { According to Arnett (2007), had Luther grown up in a different } \\
\text { time and place, he would have developed a much different } \\
\text { identity. }\end{array}$ & $\begin{array}{l}15 \\
(3.16 \%)\end{array}$ \\
\hline b & $\begin{array}{l}\text { According to Arnett (2007, p. 177), “Had Luther grown up } \\
\text { in a different time and place, he would have developed a } \\
\text { much different identity.” }\end{array}$ & $\begin{array}{l}\mathbf{3 5 5} \\
\mathbf{( 7 5 \% )}\end{array}$ \\
\hline c & $\begin{array}{l}\text { Had Luther grown up in a different time and place, he would have } \\
\text { developed a much different identity. }\end{array}$ & $\begin{array}{l}10 \\
(2.1 \%)\end{array}$ \\
\hline d & All of the above are plagiarised. & $\begin{array}{l}95 \\
(20 \%)\end{array}$ \\
\hline
\end{tabular}

\begin{tabular}{|l|l|l|}
\hline & QUIZ3 & \\
\hline Option & $\begin{array}{l}\text { Read the following passage from page 197 of your textbook. } \\
\text { "Fathers usually reported being in a good mood during the rare } \\
\text { times they and their adolescents were doing something together". } \\
\text { Which of the following does NOT constitute plagiarism of the } \\
\text { passage? }\end{array}$ & $\begin{array}{l}\text { N chosen } \\
(\%)\end{array}$ \\
\hline a & $\begin{array}{l}\text { During the rare times fathers and their adolescents were doing } \\
\text { something together, fathers usually reported being in a good } \\
\text { mood. }\end{array}$ & $\begin{array}{l}24 \\
(5.2 \%)\end{array}$ \\
\hline b & $\begin{array}{l}\text { Although fathers and adolescent daughters did not } \\
\text { spend much time together, fathers tended to enjoy the } \\
\text { time they did share (Arnett, 2007). }\end{array}$ & $\begin{array}{l}\mathbf{3 2 0} \\
\mathbf{( 6 9 . 4 \% )}\end{array}$ \\
\hline c & $\begin{array}{l}\text { Fathers usually reported being in a good mood during the rare } \\
\text { times they and their adolescents were doing something together } \\
\text { (Arnett, 2007). }\end{array}$ & $\begin{array}{l}75 \\
(16.3 \%)\end{array}$ \\
\hline d & None of the above constitutes plagiarism. & $\begin{array}{l}72 \\
(9.1 \%)\end{array}$ \\
\hline
\end{tabular}

\begin{tabular}{|l|l|l|}
\hline & QUIZ4 & \\
\hline Option & $\begin{array}{l}\text { Read the following passage that was taken from page 325 of your } \\
\text { textbook: “Certainly it is true that with longer school days, a } \\
\text { longer school year, cram schools, and private tutors, J apanese } \\
\text { adolescents have far less time for after-school leisure and } \\
\text { informal socializing with friends than American adolescents do } \\
\text { (Rohlen, 1983; Stevenson \& Zusho, 2002).” Which of the } \\
\text { following does NOT plagiarise the above passage? }\end{array}$ & $\begin{array}{l}\text { N chosen } \\
\text { (\%) }\end{array}$ \\
\hline a & $\begin{array}{l}\text { It is true that because of longer school days, a longer school year, } \\
\text { cram schools and private tutors, J apanese adolescents have far } \\
\text { less time for after-school leisure and informal socializing than } \\
\text { American adolescents do (Rohlen, 1983; Stevenson \& Zusho, } \\
\text { 2002). }\end{array}$ & 14 (3.1\%) \\
\hline b & $\begin{array}{l}\text { Japanese adolescents have far less time for after-school leisure } \\
\text { and informal socializing with friends than American adolescents }\end{array}$ & 40 (8.8\%) \\
\hline
\end{tabular}




\begin{tabular}{|l|l|l|}
\hline & $\begin{array}{l}\text { do because of longer school days, a longer school year, cram } \\
\text { schools, and private tutors (Rohlen, 1983; Stevenson \& Zusho, } \\
\text { 2002; as cited in Arnett. 2007). }\end{array}$ & \\
\hline C & $\begin{array}{l}\text { In Japan, adolescents do not have much time for } \\
\text { extracurricular activities because they spend so much } \\
\text { more time with schooling than American students do } \\
\text { (Rohlen, 1983; Stevenson \& Zusho, 2002; as cited in } \\
\text { Arnett. 2007). }\end{array}$ & $\mathbf{3 7 5}$ \\
\hline d & $\begin{array}{l}\text { All of the above are plagiarised. } \\
\text { (8) }\end{array}$ & \\
\hline
\end{tabular}

Turning to the Psychology student paraphrases, the majority contained at least one instance of plagiarised text (word string, substitution, addition, deletion, or reversal). As can be seen in Table 3, using substitutions (453 instances) was the most common type of plagiaristic behaviour. This was followed by word strings (376 instances). Fewer occurrences of the other behaviours were observed: 58 additions, 34 deletions, and 18 reversals.

Table 3

Number of Instances of Plagiarised Segments (420 Psychology Students)

Original passage: "Although nearly all Trukese males in their teens and twenties engage in these activities, their externalizing escapades are limited to the weekends, and they rarely drink or fight during the week."

Types of Plagiaristic Behaviour

Number of instances (range per paraphrase)

Word string: three or more words in a row taken from the 376 original text without quotation marks.

(0-4 per paraphrase)

Substitution: modification of original wording by substitution of one to two synonymous words, or by substitution of a preposition.

Addition: Addition of one to four words to the original text.

453

(0-6 per paraphrase)

Deletion: Elimination of one to four words from the original

58 text.

(0-2 per paraphrase) 34

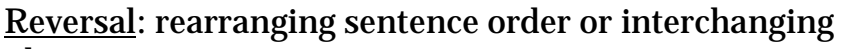
(0-2 per paraphrase) phrases.

(0-2 per paraphrase)

For the University group, most students got the first plagiarism scenario correct ( $58 \%$ of undergraduates and $52 \%$ of graduates). For Scenario 2, 62\% of undergraduates and $66 \%$ of graduate students correctly recognized the reasons why a particular paraphrase was plagiarised. A slim majority of students got the correct answer for 
Scenario 3 (50\% of undergraduates and $55 \%$ of graduate students). Results for Scenario 4 revealed that a minority of students selected the correct answer ( $26 \%$ of undergraduate students and $36 \%$ of graduate students). Table 4 shows the number and percentages of options chosen for the four scenarios.

Table 4

Number and Percentages of Options Chosen for the Scenarios for the University Group

\begin{tabular}{|c|c|c|c|}
\hline & SCENARIO 1 & & \\
\hline Option & $\begin{array}{l}\text { "In the area of intelligence testing, an interminable debate } \\
\text { has raged between those (following Charles Spearman) who } \\
\text { believe in a general factor of intellect and those (following } \\
\text { L. L. Thurstone) who posit a family of primary mental } \\
\text { abilities, with none preeminent among them." } \\
\text { The above quotation was taken from Gardner (2011, p. 7). } \\
\text { Gardner, H. (2011). Frames of mind: The theory of multiple } \\
\text { intelligences (3rd Edition). New York, NY, USA: Basic } \\
\text { Books. Retrieved from } \\
\text { http:// site.ebrary.com/ lib/ athabasca/ Doc?id=10449816\&p } \\
\text { pg=62 } \\
\text { Which of the following is a good paraphrase of the } \\
\text { quotation? }\end{array}$ & $\begin{array}{l}\text { N } \\
\text { chosen } \\
(\%) \\
\text { under- } \\
\text { grads }\end{array}$ & $\begin{array}{l}\mathrm{N} \\
\text { chosen } \\
(\%) \\
\text { grads }\end{array}$ \\
\hline $\mathrm{a}$ & $\begin{array}{l}\text { Those who posit a family of primary mental abilities are in a } \\
\text { debate with those who believe in a general factor of intellect } \\
\text { (Gardner, 2011). }\end{array}$ & $\begin{array}{l}7.5 \\
(6 \%)\end{array}$ & $\begin{array}{l}10.3 \\
(10 \%)\end{array}$ \\
\hline b & $\begin{array}{l}\text { There is still controversy as to whether intelligence } \\
\text { is a general trait or if it consists of a number of } \\
\text { different abilities (Gardner, 2011). }\end{array}$ & $\begin{array}{l}72.5 \\
(58 \%)\end{array}$ & $\begin{array}{l}53.56 \\
(52 \%)\end{array}$ \\
\hline $\mathrm{C}$ & $\begin{array}{l}\text { With regard to the area of intelligence testing, a debate has } \\
\text { raged between those who believe in a general factor and } \\
\text { those who posit a family of primary mental abilities, with } \\
\text { none dominant among them (Gardner, 2011). }\end{array}$ & $\begin{array}{l}13.75 \\
(11 \%)\end{array}$ & $\begin{array}{l}11.33 \\
(11 \%)\end{array}$ \\
\hline $\bar{d}$ & $\begin{array}{l}\text { In the area of testing intelligence, "an interminable debate" } \\
\text { (p. 7) has erupted between those who follow Charles } \\
\text { Spearman who believe in a general factor of intelligence } \\
\text { and those who follow L. L. Thurstone who postulate a } \\
\text { family of mental abilities, with none of them preeminent } \\
\text { (Gardner, 2011). }\end{array}$ & $\begin{array}{l}30 \\
(24 \%)\end{array}$ & $\begin{array}{l}27.81 \\
(27 \%)\end{array}$ \\
\hline
\end{tabular}




\begin{tabular}{|c|c|c|c|}
\hline & SCENARIO 2 & & \\
\hline Option & $\begin{array}{l}\text { "The increasing study of realistic and practically useful } \\
\text { mathematical models in population biology, whether we are } \\
\text { dealing with a human population with or without its age } \\
\text { distribution, population of an endangered species, bacterial } \\
\text { or viral growth and so on, is a reflection of their use in } \\
\text { helping to understand the dynamic processes involved and } \\
\text { in making practical predictions." } \\
\text { The above quotation was taken from Murray (2002, p. 1). } \\
\text { Murray, J. D. (2002). Mathematical biology: An } \\
\text { introduction. Secaucus, NJ , USA: Springer. Retrieved from } \\
\text { http:// site.ebrary.com/ lib/ athabasca/ Doc?id=1004776\&p } \\
\text { pg=25 } \\
\text { What, if anything, is wrong with the following paraphrase? } \\
\text { Mathematical models in biology are increasingly studied as } \\
\text { realistic and practical. This is true regardless as to whether } \\
\text { we are studying the human population, an endangered } \\
\text { species population, or bacterial or viral growth. It is a } \\
\text { reflection of their use in helping to understand the dynamic } \\
\text { processes involved and in making practical predications } \\
\text { (Murray, 2002, p. 1). }\end{array}$ & $\begin{array}{l}\mathrm{N} \\
\text { chosen } \\
\text { (\%) } \\
\text { under- } \\
\text { grads }\end{array}$ & $\begin{array}{l}\mathrm{N} \\
\text { chosen } \\
\text { (\%) } \\
\text { grads }\end{array}$ \\
\hline $\mathrm{a}$ & $\begin{array}{l}\text { Some of the word sequences are taken from the original } \\
\text { source and should be in quotation marks. }\end{array}$ & $\begin{array}{l}18.75 \\
(15 \%)\end{array}$ & $\begin{array}{l}13.39 \\
(13 \%)\end{array}$ \\
\hline b & The paraphrase follows the original passage too closely. & $\begin{array}{l}20 \\
(16 \%)\end{array}$ & $\begin{array}{l}15.45 \\
(15 \%)\end{array}$ \\
\hline $\mathbf{C}$ & Both of the above. & $\begin{array}{l}77.5 \\
(62 \%)\end{array}$ & $\begin{array}{l}67.98 \\
(66 \%)\end{array}$ \\
\hline $\mathrm{d}$ & Nothing is wrong with the paraphrase & $\begin{array}{l}8.75 \\
(7 \%)\end{array}$ & $\begin{array}{l}7.21 \\
(7 \%)\end{array}$ \\
\hline
\end{tabular}

\begin{tabular}{|c|c|c|c|}
\hline & SCENARIO 3 & & \\
\hline Option & $\begin{array}{l}\text { "One thing that all Canadians are supposed to have is } \\
\text { universal access to health care and to quality primary and } \\
\text { secondary education. Unfortunately, the last few } \\
\text { government cutbacks to social programs have undermined } \\
\text { the universality of access to these social programs, at least } \\
\text { for the lower of these three strata of society.” } \\
\text { The above quotation was taken from Phillips (2003, p. 2). } \\
\text { Phillips, P. (2003). Inside capitalism: An introduction to } \\
\text { political economy. Winnipeg, MB, CAN: Fernwood } \\
\text { Publishing. Retrieved from } \\
\text { http:// site.ebrary.com/lib/ athabasca/ Doc?id=10192216\&p } \\
\text { pg=9 } \\
\text { Which of the following is a good paraphrase of the } \\
\text { quotation? }\end{array}$ & $\begin{array}{l}\text { N } \\
\text { chosen } \\
(\%) \\
\text { under- } \\
\text { grads }\end{array}$ & $\begin{array}{l}\text { N } \\
\text { chosen } \\
\text { (\%) } \\
\text { grads }\end{array}$ \\
\hline $\mathbf{a}$ & $\begin{array}{l}\text { Although an important aspect to Canadians is } \\
\text { universal health care and good quality education, } \\
\text { recent government cuts have meant that these are } \\
\text { "universal" only to the rich (Phillips, 2003). }\end{array}$ & $\begin{array}{l}62.5 \\
(50 \%)\end{array}$ & $\begin{array}{l}56.65 \\
(55 \%)\end{array}$ \\
\hline b & $\begin{array}{l}\text { For the lower strata of society, government cutbacks to } \\
\text { social programs have undermined the universality of } \\
\text { access. This is despite the fact that one thing all Canadians } \\
\text { are supposed to have is universal access to health care and } \\
\text { to quality education (Phillips, 2003). }\end{array}$ & $\begin{array}{l}41.25 \\
(33 \%)\end{array}$ & $\begin{array}{l}32.96 \\
(32 \%)\end{array}$ \\
\hline $\mathrm{C}$ & $\begin{array}{l}\text { One thing that all Canadians are supposed to have is } \\
\text { universal access to health care and quality education. }\end{array}$ & $\begin{array}{l}17.5 \\
(14 \%)\end{array}$ & $\begin{array}{l}13.39 \\
(13 \%)\end{array}$ \\
\hline
\end{tabular}




\begin{tabular}{|c|c|c|c|}
\hline & $\begin{array}{l}\text { Unfortunately, government cuts to social programs have } \\
\text { undermined this, at least for the lower of the three strata of } \\
\text { society (Phillips, 2003, p.2). }\end{array}$ & & \\
\hline $\mathrm{d}$ & $\begin{array}{l}\text { All Canadians are supposed to have universal access to } \\
\text { health care. They are also supposed to have access to } \\
\text { quality primary and secondary education. It's a shame, but } \\
\text { the last few government cutbacks have been to social } \\
\text { programs which have undermined the universality of } \\
\text { access, at least for the lower of the three strata of society }\end{array}$ & $\begin{array}{l}3.75 \\
(3 \%)\end{array}$ & $\begin{array}{l}1.03 \\
(1 \%)\end{array}$ \\
\hline
\end{tabular}

\begin{tabular}{|l|l|l|l|}
\hline Option & SCENARIO 4 & $\begin{array}{l}\text { "The relationship of social scientists to politics in English } \\
\text { Canada can be analyzed in terms of two roles which, } \\
\text { though not mutually exclusive, have not overlapped to any } \\
\text { considerable extent in practice." } \\
\text { The above quotation was taken from Brooks \& Gagnon } \\
\text { (1988, p. 119). Brooks, S. \& Gagnon, A.-G. (1988). Social } \\
\text { scientists and politics in Canada: Between Clerisy and } \\
\text { Uanquard. Montreal, Quebec, Canada: MoGill-Queen's } \\
\text { grads } \\
\text { University Press. } \\
\text { Which of the following is a good paraphrase of the } \\
\text { quotation? }\end{array}$ & $\begin{array}{l}\text { Nos } \\
\text { chon } \\
\text { grads }\end{array}$ \\
\hline a & $\begin{array}{l}\text { There are two roles for social scientists who study politics } \\
\text { in English Canada. They are not mutually exclusive, but } \\
\text { have not overlapped to any extent in practice (Brooks \& } \\
\text { Gagnon, 1988). }\end{array}$ & $\begin{array}{l}11.25 \\
\mathbf{( 9 \% )}\end{array}$ & $\begin{array}{l}5.15 \\
(5 \%)\end{array}$ \\
\hline b & $\begin{array}{l}\text { When studying the relationship of social scientists to } \\
\text { politics in English Canada, there are two roles with little } \\
\text { overlap (Brooks \& Gagnon, 1988). }\end{array}$ & $\begin{array}{l}57.5 \\
(46 \%)\end{array}$ & $\begin{array}{l}42.23 \\
(41 \%)\end{array}$ \\
\hline C & $\begin{array}{l}\text { Social scientists who study English Canada's } \\
\text { politics can take two distinct positions (Brooks \& } \\
\text { Gagnon, 1988). }\end{array}$ & $\begin{array}{l}\mathbf{3 2 . 5} \\
\mathbf{( 2 6 \% )}\end{array}$ & $\begin{array}{l}\mathbf{3 7 . 0 8} \\
\mathbf{( 3 6 \% )}\end{array}$ \\
\hline d & $\begin{array}{l}\text { Two roles can be used to analyze the relationship of social } \\
\text { scientists to politics in English Canada, which are not } \\
\text { mutually exclusive, but have not overlapped in practice } \\
\text { (Brooks \& Gagnon, 1988). }\end{array}$ & $\begin{array}{l}23.75 \\
(19 \%)\end{array}$ & $\begin{array}{l}18.54 \\
(18 \%)\end{array}$ \\
\hline
\end{tabular}

\section{Discussion}

The objective of this project was to assess the ability of students taking online courses to recognize plagiarised material. A second objective was to explore whether this ability improved with feedback and practice by having students attempt a paraphrase. A further objective was to classify the types of errors made. This study found that almost half of the students in a third-year psychology course did not recognize plagiarised material consistently. The evidence does not support the prediction that the Psychology student scores would improve over time given feedback and practice, as more students got the first question correct (93.8\%) than the fourth question (82.2\%). Furthermore, the majority of these students did not correctly paraphrase a passage they were asked to write in their own words, even after they had received feedback on their recognition 
quizzes. This suggests more extensive instruction is needed. The University group also failed to recognize many plagiarised passages that included word strings, reversals, substitutions, additions, and deletions. As suggested by Hochstein et al. (2008), the poor ability of students to identify plagiarised passages may imply poor understanding of the concept. Therefore, when these students write their course assignments and other written work, they may not be able to recognize their own tendency toward plagiarism and thus engage in it accidentally.

\section{Types of Plagiaristic Errors}

Characterizing the types of errors students made can provide guidance for future work in plagiarism prevention. In evaluating the types of errors committed, four pieces of evidence are considered: (1) four Quiz recognition items from the 420 Psychology students; (2) paraphrases created by these Psychology students; (3) four Scenario recognition items from 125 undergraduate students from the University group; (4) the same four Scenario items answered by 103 graduate students from the University group.

One important finding is that many students seemed to believe that plagiarism had not been committed if a source was included in the rewritten passage, even if the new passage was taken word for word from the original. This was evident in the option selected by 3.2\% of Psychology students for Quiz 2, 16.3\% for Quiz 3, and 8.8\% for Quiz 4. Stronger evidence comes from the paraphrases of the 420 Psychology students; in 215 instances, students added the citation from the original text (although these citations were not always done correctly). This fits with Roig's conclusion, back in 1997, that students believed that as long as a source was cited, plagiarism was not being committed. Other evidence from the literature also finds that students place emphasis on the presence of a citation in their judgments of plagiarism (Holt, 2012).

While it is good that students are aware of the importance of citing sources, evidence suggests they often do not do this properly (Ellery, 2008; Zimitat, 2008). Educating students about the correct documentation for their discipline is important (Breen \& Maassen, 2005), but students need to learn that using their own words when rewriting text is also important. Students would also benefit from learning to use quotation marks properly (Holt, 2012), as 25\% of Psychology students did not select the option that included a proper quotation and citation in Quiz 2.

Recognising that reversing the order of words from the original source is considered plagiarism seems to be another weakness for students. Two multiple choice questions in the Psychology course contained an option in which the wording of the original was reversed. For Quiz 3, 5.2\% of students incorrectly selected this option. For Quiz 4, 8.8\% chose this option. For the University group, 33\% of undergraduates and 32\% of graduate students for Scenario 3 and $6 \%$ of undergraduate students (10\% of graduate students) for Scenario 1 incorrectly selected the item with reversed wording as the passage that was not plagiarised. Since correct citations were provided for the four 
Scenarios rated by students from the University group, perhaps the next clue that students use to classify a passage as non-plagiarised is that the words are not in identical order. Work from Dawson and Overfield (2006) supports this, as their students also had more difficulty recognizing plagiarism when a reversal was used than when words were taken directly from the original.

Interestingly, although the recognition items suggest students do not perceive reversals as plagiarism, the Psychology students used very few reversals in their own paraphrases. Only 18 instances of reversals were recorded among the 420 Psychology students. This discrepancy between performance in recognition and production tasks makes it difficult to judge whether or not reversals are a difficulty for students in their writing. One possibility is there is a disconnect between what students recognize and what they produce. Kirsch and Bradley (2012) reported a similar result, in that while only 53.5\% of students correctly chose the paraphrased option on a multiple choice quiz, up to $76.25 \%$ of them were able to produce a good paraphrase. This is an area for further research.

After citations and reversals, the most common incorrect option was the one containing word strings (identical words to the original passage) along with substitutions and/ or deletion(s) and/or addition(s) that hold the paraphrase together. These options were chosen by 3.8\% of Psychology students in Quiz 1 and 3.1\% of students in Quiz 4. For the University group, $24 \%$ of undergraduates ( $27 \%$ of graduates) chose this option for Scenario 1, for Scenario 3, 14\% (13\% of graduate students) chose this option, and for Scenario $4,19 \%$ of undergraduates (18\% of graduate students) selected this option. In comparison, Psychology students' paraphrases in Quiz 5 included a moderate amount of additions and deletions (58 and 34 instances, respectively). However, at 453 instances, substitutions were by far the most common type of plagiarism used in the paraphrasing task.

Although the present study found that students had some difficulty recognizing plagiarism in phrases that contained substitutions, additions, and deletions, students in the study by Dawson and Overfield (2006) had the greatest amount of difficulty with such phrases. Because students tend to use substitutions frequently in their own writing (as evidenced in the paraphrasing task in the present study) this may indicate they do not consider this as plagiarism. Dawson and Overfield did not report use of citations (the main cue used by students in the present study), so the reason for the discrepancy between their study and this one as to the degree to which students incorrectly perceive using substitutions as a way to paraphrase is not clear. However, both studies concur that sticking closely to the original text (rather than focusing on summarizing the meaning of the passage) may be a weakness among students. Howard (1995) claimed "patchwriting" (p. 799), in which a few changes are made to the original text, was a necessary step through which beginning students learn to engage in academic writing. However, she also stated that final papers should not be handled in this way. Clearly students need more instruction in understanding plagiarism. 
An unexpected result in this study was that the majority of students from the University group did not select the correct option for Scenario 4 (see Table 4). The modal (incorrect) response was an option that had fewer words than most of the other options. It may be that when phrases are correctly paraphrased, they tend to be shorter than the original passage. Some support for this notion comes from Walker's (2008) finding that students who had been trained in proper paraphrasing used fewer words in their rewrites than did students in the control group. However, further research is needed to test this.

\section{Conclusion}

Becoming familiar with terminology, time management, learning how to read academic papers for meaning and how to summarize the main points of a text, in addition to learning proper citation rules and how to avoid plagiarism, are essential skills for students in higher education. Currently, instructors may be overestimating students' abilities in these areas. Rather than perceiving poor paraphrasing as a type of cheating, it may be more appropriate to identify it as a weakness in skills. Knowing where student weaknesses lie provides essential information as to where to direct intervention. Educating students about avoiding substitutions, word strings, reversals, additions, and deletions may be a first step in preventing accidental plagiarism.

If it is true that a large number of students do not fully understand plagiarism, proactive prevention rather than punishment may be the best means to deal with it. Several authors suggest training in skill development is key. Soto et al. (2004) and Zimitat (2008) observed that students who plagiarised did not have good note-taking skills. They recommended that students be taught such skills, but whether this is a causal or merely correlational relationship requires future investigation.

Information literacy has been touted as a crucial factor in preventing plagiarism (Moniz et al., 2008; Rolfe, 2011). Reading peer-reviewed journal articles, as is often asked of students in higher education, can be very difficult. Students may need guidance in their selection of journals, but even more so, students may need to be taught how to read such articles. Prevention may need to focus on helping students grasp the main ideas and summarize material rather than focusing on details (Walker, 2008). This may help ensure "students don't conclude that creating a technically perfect bibliography is enough" (Howard \& Davies, 2009, p. 65).

Requiring that students pass a test that demonstrates they have the necessary skills could be a prerequisite to handing in their assignments. Several such online tutorials exist (see Reference note). Currently instructors may be asking students to perform "what they have not been taught" (Levin, 2006, p. 6). To label the outcome as cheating may be an act of misconduct on the part of academic staff. 


\section{Acknowledgements}

I would like to thank Lara Apps for her research assistance and editorial skills. Thanks go to Marti Cleveland-Innes and Terry Anderson for reviewing previous drafts of this article. Much appreciation goes to Nancy Parker and Cindy Ives for allowing me access to data from their academic integrity project. I would also like to acknowledge the generous support in kind from my university.

\section{Reference note}

- Plagiarism Resource Site http://abacus.bates.edu/cbb/index8698.html?q=node/ 60

- Welcome to the plagiarism tutorial http:// www.lib.usm.edu/legacy/plag/plagiarismtutorial.php

- Quoting and paraphrasing sources http:// writing.wisc.edu/Handbook/QPA_paraphrase.html

- The cite is right: quiz show http:// library.camden.rutgers.edu/EducationalModule/ Plagiarism/ citeisright.html

- Plagiarism tutorial http:// www.lib.sfu.ca/help/tutorials/plagiarism-tutorial

- Plagiarism game: http:// www.lycoming.edu/library/instruction/tutorials/plagiarismGame.aspx 


\section{References}

Ashworth, P., Bannister, P., \& Thorne, P. (1997). Guilty in whose eyes? University students' perceptions of cheating and plagiarism in academic. Studies in Higher Education, 22(2).

Baker, R. K., Berry, P., \& Thornton, B. (2008). Student attitudes on academic integrity violations. J ournal of College Teaching \& Learning, 5(1), 5-13.

Barry, E. S. (2006). Can paraphrasing practice help students define plagiarism? College Student J ournal, 40(2), 377-384.

Breen, L., \& Maassen, M. (2005). Reducing the incidence of plagiarism in an undergraduate course: The role of education. Issues in Educational Research, 15(1), 1-16.

Briggs, R. (2009). Shameless! Reconceiving the problem of student plagiarism. Angelaki, 14(1), 65-75.

Chai, C. (J uly 7, 2010). Easier feat to cheat: Internet blamed as majority of students admit to academic dishonesty. Canwest News Service.

Christensen-Hughes, J . M., \& McCabe, D. L. (2006). Understanding academic misconduct. Canadian J ournal of Higher Education, 36(1), 49 - 63.

Davis, S. F., \& Ludvigson, H. W. (1995). Additional data on academic dishonesty and a proposal for remediation. Teaching of Psychology, 22(2), 119-121.

Dawson M. M, \& Overfield, J . A. (2006). Plagiarism: Do students know what it is? Bioscience Education, 8 (Article 1). doi:10.3108/ beej.8.1

Dee, T. S., \&J acob, B. A. (2012). Rational ignorance in education: A field experiment in student plagiarism. The J ournal of Human Resources, 47(2), 397-434.

Elandera, J ., Pittamb, G., Lusherc, J ., Fox, P., \& Paynee, N. (2010). Evaluation of an intervention to help students avoid unintentional plagiarism by improving their authorial identity. Assessment \& Evaluation in Higher Education, 35(2), 157- 171.

Ellery, K. (2008). Undergraduate plagiarism: A pedagogical perspective. Assessment \& Evaluation in Higher Education, 33(5), 507- 516.

Ercegovac, Z., \& Richardson, J . V. (2004). Academic dishonesty, plagiarism included, in the digital age: A literature review. College \& Research Libraries, 65(4), 301318. 
Hale, J . L. (1987). Plagiarism in classroom settings. Communication Research Reports, 4(2), 66-70.

Hansen, B. (2003). Combating plagiarism. CQ Researcher, 13(32), 775-796.

Hochstein, D. D., Brewer, J ., Steinke, M. D., \& Taylor, J . D. (2008). Examining the issue of academic plagiarism: What do students at Wright State University Lake Campus know about plagiarism? Association for University Regional Campuses of Ohio J ournal, 14, 59-82.

Holt, E. A. (2012). Education improves plagiarism detection by biology undergraduates. BioScience, 62(6) 585-592.

Howard, R. M. (1995). Plagiarisms, authorships, and the academic death penalty. College English, 57(7), 788- 806.

Howard, R. M., \& Davies, L. J . (2009). Plagiarism in the Internet age. Educational Leadership, March, 64-67.

J ocoy, C., \&DiBiase, D. (2006). Plagiarism by adult learners online: A case study in detection and remediation. International Review of Research in Open and Distance Learning, 7(1), 1-15.

J ones, D. L. R. (2011). Academic dishonesty: Are more students cheating? Business Communication Quarterly, 74(2), 141-150. DOI: 10.1177/ 1080569911404059

J urdi, R. H., Hage, S., \& Chow, H. P. H. (2012). What behaviours do students consider academically dishonest? Findings from a survey of Canadian undergraduate students. Social Psychology of Education, 15, 1- 23. DOI 10.1007/s11218-0119166-y

Kasprzak, J ., \& Nixon, M. (2004). Cheating in cyberspace: Maintaining quality in online education. Association for the Advancement of Computing In Education, 12(1), 85-99.

Kennedy, K., Nowak, S., Raghuraman, R., Thomas, J ., \&Davis, S. F. (2000). Academic dishonesty and distance learning: Student and faculty views. College Student J ournal, 34(2), 309-314.

Kirsch, B. A., \& Bradley, L. (2012). Distance education and plagiarism prevention at the University of South Carolina Upstate. J ournal of Library \& Information Services in Distance Learning, 6(2), 79-99.

Levin, P. (2006). Why the writing is on the wall for the plagiarism police. Retrieved from http:// www.student-friendly guides.com/plagiarism/writing_on the_wall.pdf 
Marshall, S., \& Garry, M. (2005, Dec. 3-6). How well do students really understand plagiarism? Paper presented at the annual ascilite conference, Brisbane, Australia.

McCabe, D. L. (2005). Cheating among college and university students: A North American perspective. International J ournal of Educational Integrity, 1(1), 2631.

McCabe, D. L., (2009). Academic dishonesty in nursing schools: An empirical investigation. J ournal of Nursing Education, 48(11), 614-623.

McCabe, D. L., \&Trevino, L. K. (1993). Academic dishonesty, honor codes, and other contextual influences. J ournal of Higher Education, 64, 522-538.

Moniz, R., Fine, J ., \& Bliss, L. (2008). The effectiveness of direct-instruction and student-centered teaching methods on students' functional understanding of plagiarism. College \& Undergraduate Libraries, 15(3), 255-279.

Park, C. (2003). In other (people's) words: Plagiarism by university students-literature and lessons. Assessment \& Evaluation in Higher Education, 28(5), 471-488.

Roig, M. (1997). Can undergraduate students determine whether text has been plagiarised? Psychological Record, 47(1), 113-122.

Rolfe, V. (2011). Can Turnitin be used to provide instant formative feedback? British J ournal of Educational Technology, 42(4), 701- 710. doi:10.1111/j.14678535.2010.01091.x

Scanlon, P. M. (2003). Student online plagiarism: How do we respond? College Teaching, 51(4), 161-165.

Scanlon, P.M., \&Neumann, D.R. (2002). Internet plagiarism among college students. J ournal of College Student Development, 43(3), 374- 85.

Sciammarella, S. (2009). Making a difference: Library and teaching faculty working together to develop strategies in dealing with student plagiarism. Community \& J unior College Libraries, 15(1), 23-34.

Shirley, S. (2004). The art of paraphrase. Teaching English in the Two Year College, 32(2), 186-188.

Soto, J . G., Anand, S., \& McGee, E. (2004, J uly/ August). Plagiarism avoidance: An empirical study examining teaching strategies. J ournal of College Science Teaching 33(7), $42-48$. 
Stuber-McEwen, D., Wiseley, P., \&Hoggatt, S. (2009). Point, click, and cheat: Frequency and type of academic dishonesty in the virtual classroom. Online J ournal of Distance Learning Administration, XII(III).

Szabo, A. \&Underwood, J . (2004). Cybercheats: Is information and communication technology fuelling academic dishonesty? Active Learning in Higher Education, 5(2), 180-199.

Thomson Maddox, T. (2008). Plagiarism and the community college. In T. S. Roberts (Ed.), Student plagiarism in an online world. Hershey: Information Science Reference.

Turnitin (2012). The plagiarism spectrum. White Paper.

Vardi, I. (2012): Developing students' referencing skills: A matter of plagiarism, punishment and morality or of learning to write critically? Higher Education Research \& Development, 31(6), 921-930.

Varvel, V., J r. (2005). Honesty in online education. Pointers and Clickers, 6(1), 1-20. Retrieved from http:// www.ion.uillinois.edu/resources/pointersclickers/2005 01/VarvelCheat Point2005.pdf

Voss, D., \& Rosati, A. C. (2002). “It wasn't me, was it?” Plagiarism and the Web. Computers and Composition 19,191- 203.

Walker, A. L. (2008). Preventing unintentional plagiarism: A method for strengthening paraphrasing skills. J ournal of Instructional Psychology, 35(4), 387-395.

Walker, J . (2010). Measuring plagiarism: Researching what students do, not what they say they do. Studies in Higher Education, 35(1), 41-59.

Zimitat, C. (2008). Student perspective of plagiarism. In T. S. Roberts (Ed.), Student plagiarism in an online world: Problems and solutions (Chapter II., pp. 1022). Hershey: Information Science Reference.

\section{Athabasca University $\mathbf{a}$}

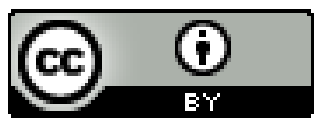

